Review

\title{
Beneficial Effects of Temperate Forage Legumes that Contain Condensed Tannins
}

\section{Jennifer W. MacAdam ${ }^{1, *}$ and Juan J. Villalba ${ }^{2}$}

1 Department of Plants, Soils and Climate, Utah State University, 4820 Old Main Hill, Logan, UT 84322, USA

2 Department of Wildland Resources, Utah State University, 5230 Old Main Hill, Logan, UT 84322, USA; E-Mail: juan.villalba@usu.edu

* Author to whom correspondence should be addressed; E-Mail: jennifer.macadam@usu.edu; Tel.: +1-435-797-2364; Fax: +1-435-797-3376.

Academic Editor: Cory Matthew

Received: 21 May 2015 / Accepted: 13 July 2015 / Published: 20 July 2015

\begin{abstract}
The two temperate forage legumes containing condensed tannins (CT) that promote ruminant production are birdsfoot trefoil (Lotus corniculatus L.; BFT) and sainfoin (Onobrychis viciifolia Scop.; SF). Both are well-adapted to the cool-temperate climate and alkaline soils of the Mountain West USA. Condensed tannins comprise a diverse family of bioactive chemicals with multiple beneficial functions for ruminants, including suppression of internal parasites and enteric methane. Birdsfoot trefoil contains 10 to $40 \mathrm{~g} \cdot \mathrm{CT} \cdot \mathrm{kg}^{-1}$ dry matter (DM), while SF contains 30 to $80 \mathrm{~g} \cdot \mathrm{CT} \cdot \mathrm{kg}^{-1} \mathrm{DM}$. Our studies have focused on these two plant species and have demonstrated consistently elevated rates of gain for beef calves grazing both BFT and SF. Novel results from our BFT research include carcass dressing percentages and consumer sensory evaluations equivalent to feedlot-finished steers and significantly greater than grass-finished steers, but with omega-3 fatty acid concentrations equal to grass-finished beef. We have further demonstrated that ruminants fed BFT or SF will consume more endophyte-infected tall fescue (Schedonorus arundinaceus (Schreb.) Dumort.) forage or seed than ruminants fed a non-CT forage legume. There is great potential value for sustainable livestock production in the use of highly digestible, nitrogen-fixing legumes containing tannins demonstrated to improve ruminant productivity.
\end{abstract}


Keywords: proanthocyanidin; birdsfoot trefoil (Lotus corniculatus L.); sainfoin (Onobrychis viciifolia Scop.)

\section{Introduction: Structural Diversity and Function of Condensed Tannins:}

Condensed tannins (CT) are a heterogeneous family of highly-reactive, carbon-based secondary compounds of high molecular weight [1] that bind to proteins with great affinity [2,3], precipitating them from solution [4]. These biomolecules, also known as polyphenolics or proanthocyanidins, cause responses in herbivores that vary with the diversity of their chemical structures $[5,6]$. Such diversity is in part due to the fact that CT are polymers of flavan-3-ol subunits, which offer the possibility of a wide array of molecular weights [7,8], ranging from dimers and trimers to oligomers with multiple subunits [9]. The structure of CT also depends on the degree of polymerization of these subunits, stereochemistry, the hydroxylation pattern on the " $A$ " and " $B$ " rings of the flavan-3-ol subunits and the presence or absence of the 3-hydroxyl group in the molecule [6,8]. In addition, CT are amphipathic molecules with aromatic (hydrophobic) rings and hydroxyl (hydrophilic) groups, allowing for bonds with different molecules, from proteins and minerals to polysaccharides and other plant secondary compounds [10].

The abundance of CT in the leaves of forest trees and early findings on the negative relationship between $\mathrm{CT}$ concentration and levels of insect herbivory led to the proposal that CT evolved as a quantitative chemical defense against insect herbivory [11]. This early view was reinforced by the fact that there are no compelling findings suggesting that CT have a fundamental role in plant physiological processes [12,13]. Nevertheless, several recent studies have failed to show a consistent protective role for CT against herbivory (i.e., [14,15]), and thus, the role of $\mathrm{CT}$ as a defensive chemical has been challenged. For instance, it has been noted that the vision of CT as toxins is at odds with the fact that humans have enjoyed CT in drinks and foods for thousands of years [4]. Moreover, recent evidence suggests that at appropriate doses, CT may enhance the nutrition and health of consumers, as well as the quality of milk and meat products [16-18].

In ruminants, the binding and precipitation of dietary proteins by $\mathrm{CT}$ shifts the site of protein digestion from the rumen to the intestines and nitrogen excretion from urine to feces [19]. Such shifts can improve the nutrition of ruminants [20] in feeds that have a greater concentration of soluble protein than is required for carbohydrate utilization by rumen microbes, which is the case with most well-managed forage legumes. Moreover, improving the protein nutrition of ruminants enhances immune responses [21,22], which may increase resistance to gastrointestinal nematodes [23]; increasing the essential and branched-chain amino acids reaching the small intestine also improves reproductive efficiency in ruminants [24]. By consuming CT-containing forages, herbivores alleviate bloat [25], reduce methane emissions [26,27] and reduce internal parasites [21]. For instance, CT-containing legumes, like sainfoin (SF; Onobrychis viciifolia Scop.), have antiparasitic activity against helminth nematodes [28], and sheep appear to recognize this benefit of SF during grazing by increasing their selection of this forage when challenged by parasitic burdens [29]. Further, when herbivores consume feeds containing CT, their meat is lighter in color, with a greater concentration of 
antioxidants and omega-3 compared with omega-6 fatty acids, reduced "pastoral" flavor [30] and is generally more desirable for human consumption $[16,17,31,32]$.

For this review, we will focus on the beneficial effects of CT and CT-containing temperate legumes in ruminant diets and the potential interactions that can enhance such effects. Both birdsfoot trefoil (BFT; Lotus corniculatus L.) and SF perform well under irrigation in the high $\mathrm{pH}$ soils and cool-temperate climate of the Mountain West USA, and both are beneficial for ruminant productivity $[4,18]$.

\section{Condensed Tannins in Temperate Forage Legumes}

The CT synthesized in forage plant species differ in molecular weight and the type and proportion of subunit (see the comprehensive appendix of [4]). The most commonly-cultivated temperate forage legumes are alfalfa (Medicago sativa L.) and white clover (Trifolium repens L.). Alfalfa expresses CT in its seed coat, and white clover expresses CT in its flowers. The selection of white clover for elevated floral CT [33] resulted in white clover shoot CT concentrations as great as $12 \mathrm{~g} \cdot \mathrm{kg}^{-1}$ dry matter (DM). Alfalfa and white clover have recently been genetically engineered to express CT in their leaves [34], but commercial release of CT-containing cultivars is anticipated to require nine years or more [35,36]. Two forage plant species that grow well in the Mountain West USA and that naturally contain significant concentrations of CT in their leaves are BFT, which contains 10 to $40 \mathrm{~g} \cdot \mathrm{CT} \cdot \mathrm{kg}^{-1} \mathrm{DM}$, and $\mathrm{SF}$, which contains 30 to $80 \mathrm{~g} \cdot \mathrm{CT} \cdot \mathrm{kg}^{-1} \mathrm{DM}[9]$.

\subsection{Grass and Legume Forages}

Grazing-based cattle and sheep production is commonly carried out on grass or mixed grass-legume pastures. The rapid digestibility and greater accessibility of proteins in legumes, such as alfalfa and white clover, can result in bloat if these forages constitute more than $25 \%$ of a pasture mixture [37] or if they occur in patches that can be selected by ruminants. However, CT concentrations as little as $5 \mathrm{~g} \cdot \mathrm{kg}^{-1} \mathrm{DM}$ can prevent bloat [38], so pastures composed of CT-containing legumes can be grazed without restriction. Ruminant intake is negatively correlated with forage fiber concentration, and intake is greater for ruminants fed legumes than grasses [39]; ruminant production on forages is a function of intake, which is typically limited by rumen fill and fiber digestion [40]. At similar stages of forage maturity, legumes have less fiber than grasses (e.g., [41]) and can be digested more readily. The protein content of forage legumes is often greater than the dietary protein requirement of ruminants, and when the available protein exceeds the available carbohydrate (i.e., energy) in the rumen, amino acids will be used for energy [42]. This results in an undesirable generation of ammonia that is excreted in urine or milk [43].

\subsection{The Beneficial Role of Some Condensed Tannins in Ruminant Digestion}

Condensed tannins prevent bloat by binding to and precipitating proteins, which reduces protein concentration in the rumen and increases rumen bypass or "undegradable" protein [44]. The CT expressed by many forages can bind to salivary proteins, reducing palatability and intake; CT can also form indigestible complexes with rumen microbes and cell wall carbohydrates, reducing the rate of rumen digestion and intake [45]. As a result, forages, such as big trefoil (Lotus pedunculatus Cav.), can 
prevent bloat, but also reduce ruminant productivity [46]. The CT in BFT is present in a relatively low concentration and is not reported to inhibit intake or digestion $[47,48]$. Birdsfoot trefoil CT precipitates excess plant proteins in the rumen, preventing bloat, but it does not suppress post-ruminal digestion of proteins or absorption in the small intestine $[4,49]$. This has resulted in consistently better productivity of sheep fed BFT compared with alfalfa [50,51] and cattle fed BFT compared with non-CT legumes [52,53].

\section{Ruminant Production on CT Legumes in the Western U.S.}

\subsection{Conventional Beef Production}

The conventional North American beef production system consists of a low-input, grazing- and hay-based cow-calf phase lasting 11 months to 12 months and a high-input feedlot phase in which a ration comprised primarily of grain is fed for three to four months, for a total of 14 months to 16 months from birth to slaughter. The resulting grain-finished beef is juicy and tender; the intramuscular fat content of the longissimus muscle of beef graded choice ranges from $4 \%$ to $8 \%$ [54]. Alternatively, weaned calves that are never fed grain, antibiotics or hormones may be certified as grass-fed beef [55] and typically are slaughtered at 18 months to 24 months [56]. The longissimus intramuscular fat concentration of grass-finished beef is approximately half that of grain-finished beef [57].

\subsection{Beef Production on a CT-Containing Forage Legume}

Birdsfoot trefoil is productive and persistent in the northern Mountain West [58], typically continuing to increase in DM yield for two years after planting [59]. In production-scale swards, mature BFT stands averaged approximately $7000 \mathrm{~kg} \cdot \mathrm{ha}^{-1}$ per year in the second and third year after planting [60], about two-thirds the DM yield of grazing types of alfalfa [59]. In a study carried out at Utah State University (USU), yearling Angus (Bos taurus) steers that were finished for 111 days (3.7 months) gained $0.55 \mathrm{~kg} \cdot \mathrm{day}^{-1}$ on introduced grass pastures, $0.95 \mathrm{~kg} \cdot \mathrm{day}^{-1}$ on BFT pastures or $1.74 \mathrm{~kg} \cdot \mathrm{day}^{-1}$ on a concentrate diet [61]. Steers that averaged $451 \mathrm{~kg}$ when treatments were initiated weighed $512 \mathrm{~kg}, 557 \mathrm{~kg}$ and $644 \mathrm{~kg}$ at slaughter when finished on grass, BFT and concentrate, respectively. Stocking densities were low; post-grazing pasture DM did not fall below $1700 \mathrm{~kg} \cdot \mathrm{ha}^{-1}$. Expressed as the number of cattle required to produce one billion pounds of beef (Table 1; adapted from [62]), estimates from USU studies for cattle finished on grass (USU grass-finished (GFD); 3.4 million) were similar to those reported for current model predictions (GFD; 3.6 million) [62]. The estimate of the number of cattle required to produce one billion pounds of beef with BFT (USU BFT), however, was 2.9 million cattle, which compared favorably with Capper's [62] estimate for feedlot finishing in a U.S. conventional system that includes growth-enhancing feed additives (2.7 million) or in a feedlot system that does not include growth-enhancing feed additives (natural; 3.0 million). Age at slaughter ranged from 14.6 months for feedlot-finished beef to 22.6 months for grass-finished beef in Capper's [62] estimate, while the USU cattle were all slaughtered at 18 months. This comparison illustrates the importance of dressing percentage, which was $62 \%$ for BFT-finished beef and $64 \%$ for feedlot-finished beef. The dressing percentage for grass-finished beef in both reports was similar: 
$57.5 \%$ for GFD and $57 \%$ for USU GFD [62]. Time to finishing for all cattle in the USU study was 18 months, while time to finishing varied from 14.6 months for feedlot-finished cattle to 22.6 months for grass-finished cattle in Capper's [62] estimate.

Table 1. Capper [62] calculated the number of days to slaughter, final weights, dressing percentage and the number of cattle required to produce 1 billion $\mathrm{kg}$ beef for three U.S. beef production systems: CON (feedlot concentrate-finished), NAT (CON without growth-enhancing feed additives) and GFD (grass-finished). Results from Pitcher [61] have been compared in columns labeled USU (Utah State University). Treatments were USU NAT (CON without growth-enhancing feed additives), USU BFT (birdsfoot trefoil-finished) and USU GFD (grass-finished). Output is the number of cattle required to produce 1 billion $\mathrm{kg}$ red meat.

\begin{tabular}{|c|c|c|c|c|c|c|}
\hline & \multicolumn{6}{|c|}{ Time in System (day) } \\
\hline & $\mathrm{CON}$ & USU NAT & NAT & USU BFT & GFD & USU GFD \\
\hline Pre-weaned beef calf & 207 & 215 & 207 & 215 & 207 & 215 \\
\hline Stocker & 123 & 216 & 159 & 216 & 159 & 216 \\
\hline Yearling finishing & $\underline{110}$ & $\underline{111}$ & $\underline{110}$ & $\underline{111}$ & $\underline{313}$ & $\underline{111}$ \\
\hline Total in days & 440 & 542 & 476 & 542 & 679 & 542 \\
\hline \multirow[t]{3}{*}{ Total in months } & 14.6 & 18 & 15.8 & 18 & 22.6 & 18 \\
\hline & \multicolumn{6}{|c|}{ Weight (kg) } \\
\hline & CON & USU NAT & NAT & USU BFT & GFD & USU GFD \\
\hline Pre-weaned beef calf & 245 & 289 & 245 & 289 & 226 & 289 \\
\hline Stocker & 122 & 162 & 122 & 162 & 67 & 162 \\
\hline Yearling finishing & $\underline{204}$ & $\underline{193}$ & $\underline{163}$ & $\underline{106}$ & $\underline{192}$ & $\underline{61}$ \\
\hline Total weight & 571 & 644 & 530 & 557 & 486 & 512 \\
\hline Dressing percentage $(\%)$ & 63.8 & 58.1 & 63.3 & 62.1 & 57.5 & 57.0 \\
\hline $\begin{array}{l}\text { Cattle required for } \\
1 \times 10^{9} \mathrm{~kg} \text { red meat }\end{array}$ & $2,745,005$ & $2,672,625$ & $2,980,715$ & $2,891,034$ & $3,585,836$ & $3,426,535$ \\
\hline
\end{tabular}

The underlining signifies that the numbers in the next row are the sums of the first three rows in both the upper and lower halves of the table.

Cattle from the three USU treatments in Table 1 were slaughtered, and steaks from the longissimus muscle were subjected to consumer sensory evaluation. For the characteristics tenderness, juiciness, degree of fattiness and overall preference, steaks from BFT-finished steers were comparable to steaks from grain-finished steers and preferred to steaks from grass-finished steers [63]. The fatty acid composition of steaks from these treatments was also determined, and the meat from grass- and BFT-finished steers had an equivalent ratios of omega-6 (n-6) to omega-3 (n-3) fatty acid concentrations, and both were less than the n-6:n-3 of grain-finished beef, with greater n-3, as well as reduced $n-6$ in BFT-finished beef [64]. Likewise, beef from cattle fed CT-containing SF had greater marbling scores, quality grades (select versus standard) and backfat thicknesses than alfalfa-fed animals. Steaks from cattle finished on CT-containing SF were redder in color than steaks from cattle finished on alfalfa and contained more unsaturated fatty acids [65].

In a 2014 grazing study, the enteric methane emissions of beef cows grazing BFT were half those of cows grazing meadow bromegrass (Bromus riparius Rehm.) [61]; we believe these are the first data 
comparing enteric methane emissions of grazed perennial grasses and CT legumes. Along with the reduction of excess rumen protein due to $\mathrm{CT}$, BFT has a relatively great concentration of non-fibrous carbohydrate [66] that could contribute to the elevated gain and dressing percentage observed for the BFT-finishing treatment.

\subsection{Dairy Production on a CT-Containing Forage Legume}

In a study carried out on a commercial organic dairy in southeast Idaho USA, an 8-ha sprinkler-irrigated grass pasture was subdivided, and 4-ha were cultivated and seeded with 'Norcen' BFT in late summer of 2011. Data were collected on establishment in autumn of 2011 and spring of 2012 [67], and forage and milk production data were collected in 2012 and 2013. Grass pastures were comprised of Lolium perenne L., Dactylis glomerata L., S. arundinaceus, Elymus repens (L.) Gould and T. repens L. Nine Holstein dairy cows rotationally grazed either the BFT or the grass pasture. Cows were also fed $2.27 \mathrm{~kg}$ of barley each day, which included a vitamin and mineral supplement, and moved to fresh paddocks after each milking (every $12 \mathrm{~h}$ ). Intake was estimated with a rising plate meter as the difference between pre-grazing and post-grazing DM. Milk production was measured at the beginning of the study and every two weeks by collecting milk from each cow at four successive (two morning and two evening) milkings.

Forage intake and milk production were significantly greater on BFT in 2012 and 2013 (Table 2). A medium cheddar cheese was made from the milk of cows grazing grass and BFT pastures and compared with cheese made at the same time from the milk of non-organic cows fed a total mixed ration (TMR). Cheese made from the milk of pasture-fed cows was significantly greater in omega-3 fatty acids and conjugated linoleic acid than cheese made from the milk of TMR-fed cows. The omega-3 fatty acid concentration of cheese made from the milk of BFT-fed cows was also significantly greater than that of cheese made from the milk of grass-fed cows (Figure 1).

Birdsfoot trefoil is a tap-rooted legume, like alfalfa, giving it an agronomic advantage over grasses [68] even under irrigation in an environment that has low humidity and elevated evapotranspiration, such as the semi-arid Mountain West. The BFT was inoculated with Mesorhizobium loti, so it was receiving nitrogen from a symbiotic relationship with soil bacteria. Legumes typically have more crude protein and less neutral detergent fiber than grasses [69], which increases the rate of forage digestion, resulting in greater intake [70]. Dairy intake and production on BFT pastures likely benefitted from the combined effects of plant adaptation, morphology, nutritive value and $\mathrm{CT}$ concentration.

Table 2. Mean intake and milk production on pastures in 2012 and 2013.

\begin{tabular}{ccccc|cccc}
\hline Year & BFT Intake & SEM & Grass Intake & SEM & $\begin{array}{c}\text { BFT Milk } \\
\text { Production }\end{array}$ & SEM & $\begin{array}{c}\text { Grass Milk } \\
\text { Production }\end{array}$ & SEM \\
\hline \multicolumn{7}{c}{$\mathrm{kg} / \mathrm{ha}$} \\
$\mathbf{2 0 1 2}$ & 1603 & 235 & 773 & 149 & 30 & 1.4 & 25 & 1.6 \\
$\mathbf{2 0 1 3}$ & 2183 & 256 & 1301 & 181 & 35 & 0.7 & 30 & 2.1 \\
\hline
\end{tabular}



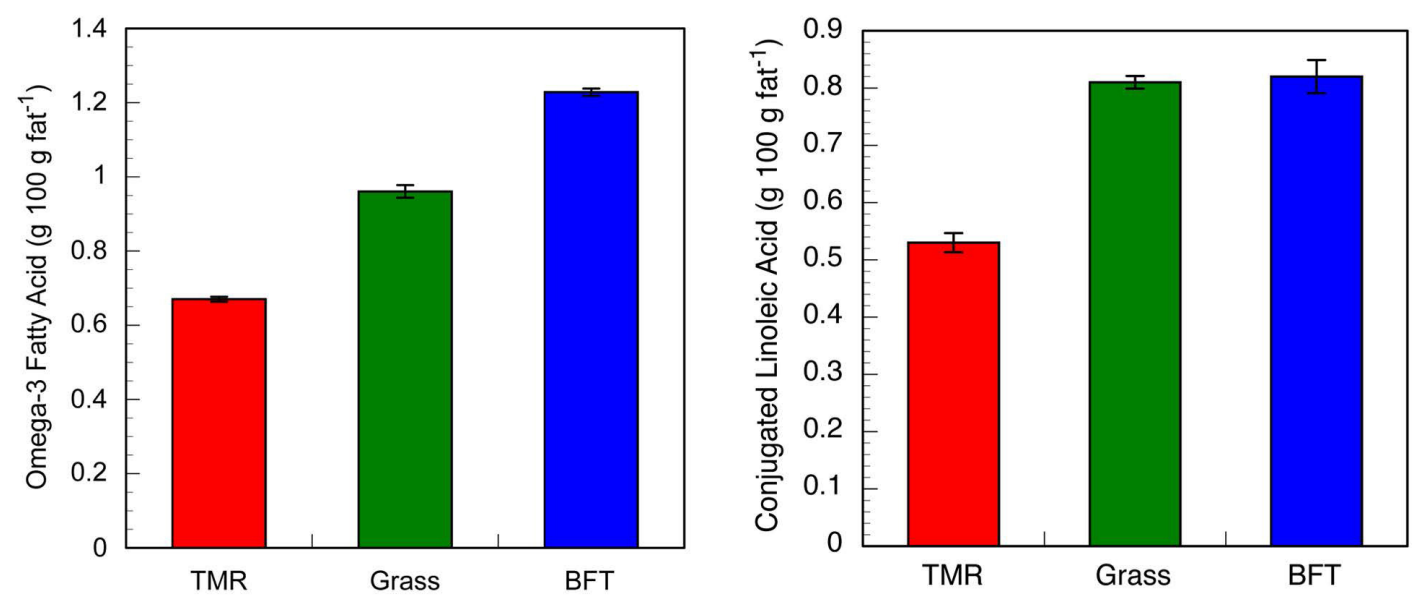

Figure 1. Omega-3 (left) and conjugated linoleic fatty acid concentrations (right) of cheese made from the milk of organic dairy cows grazing mixed grass pastures or birdsfoot trefoil (BFT) pastures, compared with cheese made from the milk of non-organic cows fed a total mixed ration (TMR).

\section{Chemical Interactions of Condensed Tannins within a Dietary Context}

The aforementioned analysis describes recent findings on the positive effects of CT and CT-containing legumes on ruminant nutrition and product quality. However, ruminants ingest a diversity of chemicals during grazing, from those present in a single forage to those ingested with a diverse diet. Thus, there is potential for multiple interactions among all of the different chemicals ingested within and between meals; this is particularly true for CT, since as stated above, these biomolecules are highly reactive.

\subsection{Interaction with Proteins}

The CT-protein interaction has been given considerable attention since the basis for the role of CT in chemical defense has been attributed to their ability to precipitate plant proteins and gastrointestinal enzymes [5,71], despite the fact that the CT-protein bond may be prevented or reversed [71].

The formation of CT complexes involves covalent and non-covalent bonding with other molecules [5]. During oxidative coupling, covalent bonds are formed by the conversion of phenols to quinones or semi-quinones, and these bonds are not reversible [2]; however, the CT-binding mechanism in a dietary context typically involves non-covalent forces (i.e., hydrogen bonds and hydrophobic interactions), which are reversible [10,72]. Condensed tannins that interact predominantly via hydrogen bonds form stronger complexes with dietary proteins than those based on hydrophobic interactions. Therefore, CT that form hydrogen bonds with proteins are more likely to result in ruminal escape proteins, while CT that interact with proteins via hydrophobic bonds form weaker complexes [4]. Condensed tannin-protein complexes formed by hydrogen bonds are stable in the rumen at $\mathrm{pH}$ values close to neutrality, but may become unstable in the more acidic (e.g., pH 2.5 to 3.0) abomasum. The protein released from the disrupted complex provides amino acids for digestion and absorption in the small intestine at $\mathrm{pH} 8.0$ to $9.0[49,73]$. 
Weaker CT-protein bonds may also mean an increased likelihood for interactions of CT with chemical structures present in the broad array of plant species ingested by herbivores, such as in pastures with diverse forage species composition [74]. Such interactions may lead to antagonistic effects that reduce the bioavailability of CT or to synergistic effects that increase their bioactivity [74]. As an example, the negative post-ingestive effects of different CT may be attenuated due to complexation when they are consumed in the same meal. It has been observed that DM intake by sheep is enhanced as the number of CT-containing shrubs in the diet increases relative to single shrub diets [75]. Likewise, phenolic compounds have been shown to have antagonistic interactions, making some of them (e.g., resveratrol) much less bioavailable when other phenols are present in the diet [76]. In contrast, other nutrient or plant chemical interactions may increase the activity or bioavailability of CT. Synergistic effects have been observed between increments in dietary calcium concentration and the bioavailability of resveratrol, a phenolic compound found in grapes and berries [77].

\subsection{Interactions with Carbohydrates}

It has been reported that greater CT concentrations depress rumen digestion of both readily fermentable and structural carbohydrates [44,46,78]. These effects are likely to be caused by an inactivation of extracellular microbial and mammalian enzymes through the formation of CT-enzyme complexes [79], rather than by a direct CT-carbohydrate interaction. In addition, CT can potentially interfere with the adhesion process of microbial bacteria onto forage cell walls, which can also lead to a depression in structural carbohydrate digestion [79].

\subsection{Interactions with Saponins}

Steroidal and triterpenoid saponins are a family of chemical compounds consisting of an isoprenoidal-derived aglycone (sapogenin), covalently linked to one or more sugar moieties [80]. Saponins are generally regarded as plant defenses, although several valuable pharmacological properties have recently been identified, such as anti-cancer, immunomodulatory and cholesterol-lowering activities [81]. In addition, saponins have been shown to reduce methane emissions [82] and to control gastrointestinal nematodes in ruminants [83]. The anthelmintic effects of CT and saponins can be explained through their toxic effects on parasites [84].

Consuming a diversity of plant secondary compounds like saponins and CT may reduce the overall toxic effect of the mix, as the formation of gastrointestinal complexes could reduce the absorption and activity of single toxic compounds [85]. In support of this, it has been found that intestinal bonding of $\mathrm{CT}$ and saponins results in moderated toxic effects, representing a mechanism that allows herbivores to consume more nutrients when offered diverse foods [86]. Condensed tannins and saponins cross-react and bind in the gastrointestinal tract, nullifying the effects of both compounds [86]. For example, goats increase intake when shrubs contain a combination of CT and saponins relative to when animals are offered single shrubs [75], and sheep offered a choice between saponin- and CT-containing rations ate more feed than animals only offered CT or saponins in single rations [87]. However, the in vivo antiparasitic effect of the CT-saponin combination was found to be less than that of the single rations [87]. Thus, a reduction in the negative impacts of $\mathrm{CT}$ or saponins on the herbivore (i.e., through inactivation) can be carried over to the endoparasite, resulting in beneficial effects for both the herbivore and the parasite. 
In other words, the complexation (and potential inactivation) of CT and saponins can be beneficial to the ruminant relative to nutrient intake, but negative in regard to its effects on parasite loads. This suggests that the value of the interaction between saponins and CT may depend on whether concern is with nutrient intake or antiparasitic activity.

\subsection{Interactions with Alkaloids}

Condensed tannins are known to complex not only with proteins and saponins, but also with alkaloids [88]. Alkaloids are nitrogen-based secondary compounds, and the strong binding capacity of CT for nitrogen-containing compounds [89] may be responsible for this interaction. Stable complexes between alkaloids and CT made alkaloids less available in the gastrointestinal tract, thus reducing their toxic effects [90]. A CT-containing legume like BFT ingested prior to eating endophyte-infected (E+) tall fescue (S. arundinaceus or reed canarygrass (Phalaris arundinacea L.), both alkaloid-containing forage grasses, enabled lambs and calves to consume more tall fescue or reed canarygrass (and therefore more energy and protein) than lambs and calves fed the same grasses without the legumes [91-93]. Likewise, lambs offered CT-containing supplements ingested more alkaloid-containing rations than lambs offered just the alkaloid-containing rations [94,95]. Lambs offered a choice of alfalfa with an elevated saponin concentration, BFT containing CT and E+ tall fescue containing alkaloids preferred alfalfa [96]. However, lambs receiving intraruminal infusions of saponins increased their preference for BFT and E+ tall fescue, and lambs receiving intraruminal infusions of CT increased their preference for $\mathrm{E}+$ tall fescue. Overall, these results support the notion that CT complex with other secondary compounds and attenuate negative post-ingestive effects of individual components of the complex.

Recent evidence further supported the interaction of CT and alkaloids: polyethylene glycol, a polymer that selectively binds to CT, reduced the benefits of SF CT on a basal diet containing E+ tall fescue in sheep [90]. These benefits included an increase in the total amount of nutrients ingested and improvements in some physiological parameters indicative of fescue toxicosis, such as reduced rectal temperatures, increased numbers of leukocytes and lymphocytes and increased plasmatic concentrations of globulin and prolactin compared with control lambs that consumed $\mathrm{E}+$ tall fescue without CT-containing SF. Radial diffusion assays [97] in which tannins with or without ergot alkaloids were precipitated as they diffused through agar containing bovine serum albumin demonstrated that ergotamine, an alkaloid from E+ tall fescue, reduced the protein binding capacity of $\mathrm{CT}$ from SF and BFT (B. Goff, personal communication). This in vitro evidence supports in vivo observations of increased intake of $\mathrm{E}+$ tall fescue seed by lambs consuming SF, but reduced intake by lambs consuming the non-CT forage legume cicer milkvetch (Astragalus cicer L.) [98].

\subsection{Interactions with Terpenes}

Terpenes are a large and diverse class of carbon-based secondary compounds, biosynthetically derived from isoprene subunits [99] and produced by a variety of plants, particularly woody species. Evidence suggests that $\mathrm{CT}$ bind to terpenes and reduce their bioavailability. When offered feeds with higher levels of terpenes and CT, sheep consumed more feed containing terpenes if they first consumed feed with CT [100]. Likewise, sheep with a preference for terpene-containing sagebrush 
(Artemisia tridentata Nutt.) consumed considerably more CT-containing bitterbrush (Purshia tridentata (Pursh) DC) than sheep with less preference for sagebrush [101]. These findings are consistent with the hypothesis that terpenes and CT interact in the digestive system of sheep. Finally, lambs offered CT- and terpene-containing feeds consumed more than when they were offered only one feed [102], which again suggests the formation of CT-terpene complexes with reduced toxicity.

\section{Conclusions}

Condensed tannins are a family of plant secondary compounds with diverse structures and multiple impacts on herbivores that can range from detrimental to beneficial. Condensed tannins can form complexes with proteins, as well as with other plant secondary compounds. The temperate forage legumes BFT and SF have CT concentrations ranging from $10 \mathrm{~g} \cdot \mathrm{kg}^{-1}$ to $80 \mathrm{~g} \cdot \mathrm{kg}^{-1}$ and protein concentrations ranging from $12 \mathrm{~g} \cdot \mathrm{kg}^{-1}$ to $25 \mathrm{~g} \cdot \mathrm{kg}^{-1}$. Their CT are generally beneficial to ruminants by eliminating bloat, suppressing internal parasites, reducing enteric methane emissions and increasing the quantity of protein that is absorbed from the intestines. Our studies have demonstrated greater productivity of beef cattle fattened on BFT compared with other forages and greater milk production of commercial dairy cows grazing BFT compared with cows grazing grass pastures in mid-summer. We have also demonstrated the attenuation of negative tall fescue endophyte effects when CT were ingested along with $\mathrm{E}+$ tall fescue. One of the next challenges in the study of CT-containing forages is to relate $\mathrm{CT}$ biochemical structures to $\mathrm{CT}$ activities within the ruminant gut, particularly to balance beneficial effects on protein digestion with suppressive effects on parasites and toxic secondary compounds.

\section{Acknowledgments}

This research was supported by the Utah Agricultural Experiment Station, Utah State University, and approved as journal paper Number 8795.

\section{Author Contributions}

The authors contributed equally to the content of this article.

\section{Conflicts of Interest}

The authors declare no conflict of interest.

\section{References}

1. Mueller-Harvey, I.; Caygill, J.C. Tannins: Their nature and biological significance. In Secondary Plant Products: Antinutritional and Beneficial Actions in Animal Feeding; Nottingham University Press: Nottingham, UK, 1999.

2. Jones, E.T.; Mangan, J.L. Complexes of the condensed tannins of sainfoin (Onobrychis viciifolia Scop.) with fraction 1 leaf protein and with submixillary mucoprotein, and their reversal by polyethylene glycol and pH. J. Sci. Food Agric. 1977, 28, 126-136.

3. Hagerman, A.E.; Robbins, C.T.; Weerasuriya, Y.; Wilson, T.C.; McArthur, C. Tannin chemistry in relation to digestion. J. Range Manag. 1992, 45, 57-62. 
4. Mueller-Harvey, I. Unravelling the conundrum of tannins in animal nutrition and health. J. Sci. Food Agric. 2006, 86, 2010-2037.

5. Zucker, W.V. Tannins: Does structure determine function? An ecological perspective. Am. Nat. 1983, 121, 335-365.

6. Dixon, R.A.; Xie, D.; Sharma, S.B. Tansley review. Proanthocyanidins-A final frontier in flavonoid research? New Phytol. 2005, 165, 9-28.

7. Kennedy, J.A.; Saucier, C.; Glories, Y. Grape and wine phenolics: History and perspective. Am. J. Enol. Vitic. 2006, 57, 239-248.

8. Xie, D.; Dixon, R.A. Proanthocyanidin biosynthesis-Still more questions than answers? Phytochemistry 2005, 66, 2127-2144.

9. Adams, D.O. Phenolics and ripening in grape berries. Am. J. Enol. Vitic. 2006, 57, 249-256.

10. Hanlin, R.L.; Hrmova, M.; Harbertson, J.F.; Downey, M.O. Review: Condensed tannin and grape cell wall interactions and their impact on tannin extractability into wine. Aust. J. Grape Wine Res. 2010, 16, 173-188.

11. Feeny, P. Effect of oak leaf tannins on larval growth of the winter moth Operopthera brumata. J. Insect Physiol. 1968, 14, 805-817.

12. McKey, D. The distribution of secondary compounds within plants. In Herbivores, Their Interaction with Secondary Plant Metabolites; Rosenthal, G.W., Janzen, D.H., Eds.; Academic Press: New York, NY, USA, 1979; pp. 55-133.

13. Waghorn, G.C. Beneficial and detrimental effects of dietary condensed tannins for sustainable sheep and goat production-Progress and challenges. Anim. Feed Sci. Technol. 2008, 147, 116-139.

14. Ayres, M.P.; Clausen, T.P.; MacLean, Jr.S.F.; Redman, A.M.; Reichardt, P.B. Diversity of structure and antiherbivore activity in condensed tannins. Ecology 1997, 78, 1696-1712.

15. Schweitzer, J.A.; Madritch, M.D.; Bailey, J.K.; LeRoy, C.J.; Fischer, D.G.; Rehill, B.J.; Lindroth, E.L.; Hagerman, A.E.; Wooley, S.C.; Hart, S.C.; et al. From genes to ecosystems: The genetic basis of condensed tannins and their role in nutrient regulation in a Populus model system. Ecosystems 2008, 11, 1005-1020.

16. Priolo, A.; Bella, M.; Lanza, M.; Galofaro, V.; Biondi, L.; Barbagallo, D.; Ben Salem, H.; Pennisi, P. Carcass and meat quality of lambs fed fresh sulla (Hedysarum coronarium L.) with or without polyethylene glycol or concentrate. Small Rum. Res. 2005, 59, 281-288.

17. Priolo, A.; Vasta, V.; Fasone, V.; Lanza, C.M.; Scerra, M.; Biondi, L.; Bella, M.; Whittington, F.M. Meat odour and flavour and indoles concentration in ruminal fluid and adipose tissue of lambs fed green herbage or concentrates with or without tannins. Animal 2009, 3, 454-460.

18. Waghorn, G.C.; McNabb, W.C. Consequences of plant phenolic compounds for productivity and health of ruminants. Proc. Nutr. Soc. 2003, 62, 383-392.

19. Woodward, S.L.; Waghorn, G.C.; Watkins, K.A.; Bryant, M.A. Feeding birdsfoot trefoil (Lotus corniculatus) reduces the environmental impacts of dairy farming. Proc. N. Z. Soc. Anim. Prod. 2009, 69, 179-183.

20. Barry, T.N.; McNeill, D.M.; McNabb, W.C. Plant secondary compounds: Their impact on nutritive value and upon animal production. In Proceedings of the XIX International Grassland Conference, Sao Paulo, Brazil, 11-21 February 2001; Wageningen Academic Publishers: Wageningen, The Netherlands, 2001; pp. 445-452. 
21. Min, B.R.; Hart, S.P. Tannins for suppression of internal parasites. J. Anim. Sci. 2003, 81, E102-E109.

22. Niezen, J.H.; Charleston, W.A.G.; Robertson, H.A.; Shelton, D.; Waghorn, G.C.; Green, R. The effect of feeding sulla (Hedysarum coronarium) or lucerne (Medicago sativa) on lamb parasite burdens and development of immunity to gastrointestinal nematodes. Vet. Parasit. 2002, 105, 229-245.

23. Min, B.R.; Pomroy, W.E.; Hart, S.P.; Sahlu, T. The effect of short-term consumption of a forage containing condensed tannins on gastro-intestinal nematode parasite infections in grazing wether goats. Small Rum. Res. 2004, 51, 279-283.

24. Min, B.R.; Fernandez, J.M.; Barry, T.N.; McNabb, W.C.; Kemp, P.D. The effect of condensed tannins in Lotus corniculatus upon reproductive efficiency and wool production in ewes during autumn. Anim. Feed Sci. Technol. 2001, 92, 185-202.

25. Waghorn, G.C. Beneficial effects of low concentrations of condensed tannins in forages fed to ruminants. In Microbial and Plant Opportunities to Improve Lignocellulose Utilization by Ruminants; Akin, D.E., Ljungdahl, L.G., Wilson, J.R., Harris, P.J., Eds.; Elsevier Science Publisher: New York, NY, USA, 1990.

26. Chung, Y.-H.; McGeough, E.J.; Acharya, S.; McAllister, T.A.; McGinn, S.M.; Harstad, O.M.; Beauchemin, K.A. Enteric methane emission, diet digestibility, and nitrogen excretion from beef heifers fed sainfoin or alfalfa. J. Anim. Sci. 2013, 91, 4861-4874.

27. Woodward, S.L.; Waghorn, G.C.; Laboyrie, P.G. Condensed tannins in birdsfoot trefoil (Lotus corniculatus) reduce methane emissions from dairy cows. Proc. N. Z. Soc. Anim. Prod. 2004, 64, $160-164$.

28. Paolini, V.; Dorchies, P.; Hoste, H. Effects of sainfoin hay on gastrointestinal nematode infections in goats. Vet. Rec. 2003, 152, 600-601.

29. Villalba, J.J.; Miller, J.; Hall, J.O.; Clemensen, A.K.; Stott, R.; Snyder, D.; Provenza, F.D. Preference for tanniferous (Onobrychis viciifolia) and non-tanniferous (Astragalus cicer) forage plants by sheep in response to challenge infection with Haemonchus contortus. Small Rum. Res. 2013, 112, 199-207.

30. Schreurs, N.M.; Lane, G.A.; Tavendale, M.H.; Barry, T.N.; McNabb, W.C. Pastoral flavor in meat product from ruminant fed fresh forages and it amelioration by forage condensed tannins. Anim. Feed Sci. Technol. 2008, 146, 193-221.

31. Vasta, V.; Nudda, A.; Cannas, A.; Lanza, M.; Priolo, A. Alternative feed resources and their effects on the quality of meat and milk from small ruminants. Anim. Feed Sci. Technol. 2008, $147,223-246$.

32. Luciano, G.; Monahan, F.J.; Vasta, V.; Biondi, L.; Lanza, M.; Priolo, A. Dietary tannins improve lamb meat colour stability. Meat Sci. 2009, 81, 120-125.

33. Burggraaf, V.T.; Kemp, P.D.; Thom, E.R.; Waghorn, G.C.; Woodfield, D.R.; Woodward, S.L. Agronomic evaluation of white clover selected for increased floral condensed tannin. Proc. N. Z. Grassl. Assoc. 2003, 65, 139-145. 
34. Hancock, K.R.; Collette, V.; Fraser, K.; Greig, M.; Xue, H.; Richardson, K.; Jones, C.; Rasmussen, S. Expression of the R2R3-MYB transcription factor TaMYB14 from Trifolium arvense activates proanthocyanidin biosynthesis in the legumes Trifolium repens and Medicago sativa. Plant Physiol. 2012, 159, 1204-1220.

35. McCaslin, M. The commercial potential for genetic engineering in alfalfa. In Proceedings of the 38th North American Alfalfa Improvement Conference, Sacramento, CA, USA, 27-31 July 2002; pp. 16-18. Available online: http://www.naaic.org/Meetings/National/2002meeting/2002 Abstracts/McCaslinSymposium.pdf (accessed on 12 May 2015)

36. University of Nebraska-Lincoln $\mathrm{Ag}$ BioSafety Education Center. Available online: http://agbiosafety.unl.edu/education/timeline.htm (accessed on 15 May 2015).

37. Majak, W.; McAllister, T.A.; McCartney, D.; Stanford, K.; Cheng, K.J. Bloat in Cattle; Alberta Agriculture and Rural Development: Edmonton, AB, Canada, 2003.

38. Barry, T.N.; McNabb, W.C. Review article: The implications of condensed tannins on the nutritive value of temperate forages fed to ruminants. Br. J. Nutr. 1999, 81, 263-272.

39. Van Soest, P.J. Symposium on factors influencing the voluntary intake of herbage by ruminants: Voluntary intake in relation to chemical composition and digestibility. J. Anim. Sci. 1965, 24, 834-843.

40. Jung, H.G.; Allen, M.S. Characteristics of plant cell walls affecting intake and digestibility of forages by ruminants. J. Anim. Sci. 1995, 73, 2774-2790.

41. Wen, L.; Kallenbach, R.L.; Williams, J.E.; Roberts, C.A.; Beuselinck, P.R.; McGraw, R.L.; Benedict, H.R. Performance of steers grazing rhizomatous and nonrhizomatous birdsfoot trefoil in pure stands and in tall fescue mixtures. J. Anim. Sci. 2002, 80, 1970-1976.

42. Hoekstra, N.J.; Schulte, R.P.O.; Struik, P.C.; Lantinga, E.A. Pathways to improving the N efficiency of grazing bovines. Eur. J. Agron. 2007, 26, 363-374.

43. Satter, L.D.; Roffler, R.E. Nitrogen requirement and utilization in dairy cattle. J. Dairy Sci. 1975, $58,1219-1237$.

44. Barry, T.N.; Manley, T.R. Interrelationships between the concentrations of total condensed tannin, free condensed tannin and lignin in Lotus sp. and their possible consequences in ruminant nutrition. J. Sci. Food Agric. 1986, 37, 248-254.

45. Reed, J.D. Nutritional toxicology of tannins and related polyphenols in forage legumes. J. Anim. Sci. 1995, 73, 1516-1528.

46. Barry, T.N.; Duncan, S.J. The role of condensed tannins in the nutritional value of Lotus pedunculatus for sheep. 1. Voluntary intake. Br. J. Nutr. 1984, 51, 493-504.

47. Ramírez-Restrepo, C.A.; Barry, T.N. Alternative temperate forages containing secondary compounds for improving sustainable productivity in grazing ruminants. Anim. Feed Sci. Technol. 2005, 120, 179-201.

48. Ramírez-Restrepo, C.A.; Barry, T.N.; López-Villalobos, N. Organic matter digestibility of condensed tannin-containing Lotus corniculatus and its prediction in vitro using cellulase/hemicellulase enzymes. Anim. Feed Sci. Technol. 2006, 125, 61-71.

49. Waghorn, G.C.; Ulyatt, M.J.; John, A.; Fisher, M.T. The effect of condensed tannins on the site of digestion of amino acids and other nutrients in sheep fed on Lotus corniculatus L. Br. J. Nutr. 1987, 57, 115-126. 
50. Douglas, G.B.; Wang, Y.; Waghorn, G.C.; Barry, T.N.; Purchas, R.W.; Foote, A.G.; Wilson, G.F. Liveweight gain and wool production of sheep grazing Lotus corniculatus and lucerne (Medicago sativa). N. Z. J. Agric. Res. 1995, 38, 95-104.

51. Marten, G.C.; Jordan, R.M. Substitution value of birdsfoot trefoil for alfalfa-grass in pasture systems. Agron. J. 1979, 71, 55-59

52. MacAdam, J.W.; Ward, R.E.; Griggs, T.C.; Min, B.R.; Aiken, G.E. Average daily gain and blood fatty acid composition of cattle grazing the non-bloating legumes birdsfoot trefoil and cicer milkvetch in the Mountain West. Prof. Anim. Sci. 2011, 27, 574-583.

53. Marten, G.C.; Ehle, F.R.; Ristau, E.A. Performance and photosensitization of cattle related to forage quality of four legumes. Crop Sci. 1987, 27, 138-145.

54. Smith, S.B.; Johnson, B.J. Marbling: Management of Cattle to Maximize the Deposition of intramuscular Adipose Tissue; Cattlemen's Beef Board and National Cattlemen's Beef Association: Centennial, CO, USA, 2014.

55. American Grassfed Association. Grassfed and Grass Pastured Ruminant Standards; American Grassfed Association: Denver, CO, USA, 2014.

56. Shattuck, K. Where corn is king, a new regard for grass-fed beef. Available online: http://healthimpactnews.com/2013/why-grass-fed-beef-is-good-for-your-health/ (accessed on 13 May 2015)

57. Van Elswyk, M.E.; McNeill, S.H. Impact of grass/forage feeding versus grain finishing on beef nutrients and sensory quality: The U.S. experience. Meat Sci. 2014, 96, 535-540.

58. Grabber, J.H.; Riday, H.; Cassida, K.A.; Griggs, T.C.; Min, D.H.; MacAdam, J.W. Yield, morphological characteristics, and chemical composition of European- and Mediterranean-derived birdsfoot trefoil cultivars grown in the colder continental United States. Crop Sci. 2014, 54, 1893-1901.

59. MacAdam, J.W.; Griggs, T.C. Irrigated Birdsfoot Trefoil Variety Trial: Forage Yields; Utah State University Cooperative Extension Service: Logan, UT, USA, 2013.

60. Hunt, S.R.; MacAdam, J.W.; Griggs, T.C. Seeding rate, oat companion crop and planting season effects on organic establishment of irrigated birdsfoot trefoil in the Mountain West USA. Crop Sci. 2015, in press.

61. Pitcher, L.R. Beef Average Daily Gain and Enteric Methane Emissions on Birdsfoot Trefoil, Cicer Milkvetch and Meadow Brome Pastures. Master's Thesis, Utah State University, Logan, UT, USA, December 2015.

62. Capper, J.L. Is the grass always greener? Comparing the environmental impact of conventional, natural and grass-fed beef production systems. Animals 2012, 2, 127-143.

63. Chail, A.; Legako, J.F.; Martini, S.; MacAdam, J.W. Consumer sensory evaluation of forage and conventional feedlot finished beef ribeye steaks. Meat Sci. 2014, 101, 120-121.

64. Chail, A.; Legako, J.F.; Martini, S.; Ward, R.; MacAdam, J.W. Comparison of proximate composition, $\mathrm{pH}$ and fatty acids of beef ribeye steaks from forage and conventional feedlot finished cattle. In Proceedings of the Reciprocal Meat Conference, Lincoln, NB, USA, 12-17 June 2015. Available online: https://guidebook.com/guide/24176/poi/3363090/?pcat= 132880 (acccessed on 15 May 2015) 
65. Maughan, B.; Provenza, F.D.; Tansawat, R.; Maughan, C.; Martini, S.; Ward, R.; Clemensen, A.; Song, X.; Cornforth, D.; Villalba, J.J. Importance of grass-legume choices on cattle grazing behavior, performance, and meat characteristics. J. Anim. Sci. 2014, 92, 2309-2324.

66. MacAdam, J.W.; Griggs, T.C. Irrigated Birdsfoot Trefoil Variety Trial: Forage Nutritive Value; Utah State University Cooperative Extension Service: Logan, UT, USA, 2013.

67. Hunt, S.R.; MacAdam, J.W.; Reeve, J.R. Establishment of birdsfoot trefoil (Lotus corniculatus) pastures on organic dairy farms in the Mountain West USA. Org. Agric. 2015, 5, 63-77.

68. Berdahl, J.D.; Karn, J.F.; Hendrickson, J.R. Dry matter yields of cool-season grass monocultures and grass-alfalfa binary mixtures. Agron. J. 2001, 93, 463-467.

69. Smith, L.W.; Goering, H.K.; Gordon, C.H. Relationships of forage compositions with rates of cell wall digestion and indigestibility of cell walls. J. Dairy Sci. 1972, 55, 1140-1147.

70. Crampton, E.W.; Donefer, E.; Lloyd, L.E. A nutritive value index for forages. J. Anim. Sci. 1960, 19, 538-544.

71. Robbins, C.T.; Hanley, T.A.; Hagerman, A.E.; Hjeljord, O.; Baker, D.L.; Schwartz, C.C.; Mautz, W.W. Role of tannins in defending plants against ruminants: Reduction in protein availability. Ecology 1987, 68, 98-107.

72. Renard, C.M.; Baron, A.; Guyot, S.; Drilleau, J.F. Interactions between apple cell walls and native apple polyphenols: Quantification and some consequences. Int. J. Biol. Macromol. 2001, 29, 115-125.

73. Mangan, J.L. Nutritional effects of tannins in animal feeds. Nutr. Res. Rev. 1988, 1, 209-231.

74. Villalba, J.J.; Provenza, F.D.; Gibson, N.; López-Ortíz, S. Veterinary medicine: The value of plant secondary compounds and diversity in balancing consumer and ecological health. In Sustainable Food Production Includes Human and Environmental Health; Springer Netherlands: Dordrecht, The Netherlands, 2014; Volume 3, pp. 165-190.

75. Rogosic, J.; Estell, R.E.; Skobic, D.; Martinovic, A.; Maric, S. Role of species diversity and secondary compound complementarity on diet selection of Mediterranean shrubs by goats. J. Chem. Ecol. 2006, 32, 1279-1287.

76. Pinelo, M.; Manzocco, L.; Nuñez, M.J.; Nicoli, M.C. Interaction among phenols in food fortification: Negative synergism on antioxidant capacity. J. Agric. Food Chem. 2004, 52, 1177-1180.

77. Liang, L.; Tajmir-Riahi, H.A.; Subirade, M. Interaction of $\beta$-lactoglobulin with resveratrol and its biological implications. Biomacromolecules 2008, 9, 50-56.

78. Barry, T.N.; Manley, T.R.; Duncan, S.J. The role of condensed tannins in the nutritional value of Lotus pedunculatus for sheep. Br. J. Nutr. 1986, 55, 123-137.

79. Bae, H.D.; McAllister, T.A.; Yanke, J.; Cheng, K.J.; Muir, A.D. Effects of condensed tannins on endoglucanase activity and filter paper digestion by Fibrobacter succinogenes S85. Appl. Environ. Microbiol. 1993, 59, 2132-2138.

80. Augustin, J.M.; Kuzina, V.; Andersen, S.B.; Bak, S. Molecular activities, biosynthesis and evolution of triterpenoid saponins. Phytochemistry 2011, 72, 435-457.

81. Guçlu-Ustundag, O.; Mazza, G. Saponins: Properties, applications and processing. Crit. Rev. Food Sci. Nutr. 2007, 47, 231-258. 
82. Hu, W.L.; Liu, J.X.; Ye, J.A.; Wu, Y.M.; Guo, Y.Q. Effect of tea saponin on rumen fermentation in vitro. Anim. Feed Sci. Technol. 2005, 120, 333-339.

83. Sinha Babu, S.P. Saponins and its possible role in the control of helminth parasites. In Recent Progress in Medicinal Plants; Sharma, S.K., Govil, J.N., Singh, V.K., Eds.; Studium Press: New Delhi, India, 2005; Volume 10, pp. 405-418.

84. Lozano, G.A. Parasitic stress and self-medication in wild animals. Adv. Study Behav. 1998, 27, 291-317.

85. Freeland, W.J.; Janzen, D.H. Strategies in herbivory by mammals: The role of plant secondary compounds. Am. Nat. 1974, 108, 269-286.

86. Freeland, W.J.; Calcott, P.H.; Anderson, L.R. Tannins and saponin: Interaction in herbivore diets. Biochem. Syst. Ecol. 1985, 13, 189-193.

87. Copani, G.; Hall, J.O.; Miller, J.; Priolo, A.; Villalba, J.J. Plant secondary compounds as complementary resources: Are they always complementary? Oecologia 2013, 172, 1041-1049.

88. Okuda, T.; Mori, K.; Shiota, M. Effects of interaction of tannins and coexisting substances. III Formation and solubilization of precipitates with alkaloids. J. Pharm. Soc. Jpn. 1982, 102, $854-858$.

89. Charlton, A.J.; Davis, A.L.; Jones, D.P.; Lewis, J.R.; Davies, A.P.; Haslam, E.; Williamson, M.P. The self-association of the black tea polyphenol theaflavin and its complexation with caffeine. J. Chem. Soc. 2000, 2, 317-322.

90. Catanese, F.; Distel, R.A.; Villalba, J.J. Effects of supplementing endophyte-infected tall fescue with sainfoin and polyethylene glycol on the physiology and ingestive behavior of sheep. J. Anim. Sci. 2014, 92, 744-757.

91. Owens, J.; Provenza, F.D.; Wiedmeier, R.D.; Villalba, J.J. Influence of saponins and tannins on intake and nutrient digestion of alkaloid-containing foods. J. Sci. Food Agric. 2012, 92, 2373-2378.

92. Lyman, T.D.; Provenza, F.D.; Villalba, J.J.; Wiedmeier, R.D. Cattle preferences differ when endophyte-infected tall fescue, birdsfoot trefoil, and alfalfa are grazed in different sequences. J. Anim. Sci. 2011, 89, 1131-1137.

93. Lyman, T.D.; Provenza, F.D.; Villalba, J.J.; Wiedmeier, R.D. Phytochemical complementarities among endophyte-infected tall fescue, reed canarygrass, birdsfoot trefoil and alfalfa affect cattle foraging. Animal 2012, 6, 676-682.

94. Lyman, T.D.; Provenza, F.D.; Villalba, J.J. Sheep foraging behavior in response to interactions among alkaloids, tannins and saponins. J. Sci. Food Agric. 2008, 88, 824-831.

95. Owens, J.; Provenza, F.D.; Wiedmeier, R.D.; Villalba, J.J. Supplementing endophyte-infected tall fescue or reed canarygrass with alfalfa or birdsfoot trefoil increases forage intake and digestibility by sheep. J. Sci. Food Agric. 2012, 92, 987-992.

96. Villalba, J.J.; Provenza, F.D.; Clemensen, A.K.; Larsen, R.; Juhnke, J. Preference for diverse pastures by sheep in response to intraruminal administrations of tannins, saponins and alkaloids. Grass Forage Sci. 2011, 66, 224-236.

97. Hagerman, A.E. Radial diffusion method for determining tannin in plant extracts. J. Chem. Ecol. 1987, 13, 437-449. 
98. Villalba, J.J.; Spackman, C.; Goff, B.; Klotz, J.L.; MacAdam, J.W. Interaction between a tannin-containing legume and endophyte-infected tall fescue seed on lambs' feeding behavior and physiology. In Proceedings of the American Society of Animal Science Annual Meeting, Orlando, FL, USA, 12-16 July 2015. Available online: http://m.jtmtg.org/abs/t/62691 (accessed on 15 February 2015)

99. Tholl, D. Terpene synthases and the regulation, diversity and biological roles of terpene metabolism. Curr. Opin. Plant Biol. 2006, 9, 297-304.

100. Mote, T.; Villalba, J.J.; Provenza, F.D. Foraging sequence influences the ability of lambs to consume foods containing tannins and terpenes. Appl. Anim. Behav. Sci. 2008, 113, 57-68.

101. Seefeldt, S.S. Consequences of selecting Ramboulliet ewes for Mountain Big Sagebrush (Artemisia tridentata ssp. vaseyana) dietary preference. Rangeland Ecol. Manag. 2005, 58, 380-384.

102. Villalba, J.J.; Provenza, F.D.; GouDong, H. Experience influences diet mixing by herbivores: Implications for plant biochemical diversity. Oikos 2004, 107, 100-109.

(C) 2015 by the authors; licensee MDPI, Basel, Switzerland. This article is an open access article distributed under the terms and conditions of the Creative Commons Attribution license (http://creativecommons.org/licenses/by/4.0/). 